the Second World War he was seconded first to the Ministry of Aircraft Production for administrative work and then to Headquarters, R.A.F. Bomber Command, where he was a member of the Operational Research Section. He was a member of the Ruwenzori Expedition in 1952, and remained in Africa for several months collecting Diatomaceae from the East African Great Lakes. $\mathrm{He}$ has published papers on the Diatomaceae and on the Ericaceae of Tropical Africa and is honorary editor of the Journal of the Royal Microscopical Society. He has for several years been a member of the Editorial Committee of the International Code for Botanical Nomenclature.

Theoretical Physics in Monash University, Melbourne:

Prof. H. C. Bolton

DR. H. C. Bolton, senior lecturer in physics in King's College, Newcastle upon Tyne (University of Durham), has been appointed the first professor of theoretical physics in Monash University, Melbourne, Australia. Dr. Bolton was educated at Bede Grammar School, Sunderland, and at King's College, London, and holds the degrees of B.Sc. and Ph.D. Prior to his present appointment he was a lecturer in the University of Nottingham. His research interests are primarily in the field of solid-state physics.

\section{United Kingdom Nuclear Power Programme}

REviewing the development of the nuclear power programme in the United Kingdom in an address to Royal Belgian Society of Engineers and Industrialists on November 15, Sir William Cook said that the United Kingdom was constructing seven large natural uranium reactors, and an eighth would be ordered soon; the first two of these would reach full power in 1962. Two nuclear stations of the same type were being constructed overseas. The Calder Hall and Chapelcross reactors were operating very satisfactorily well above the designed electrical output and at highload factors. There was a fall in capital cost from more than $£ 150 / \mathrm{kW}$. for the first station to less than $£ 100 / \mathrm{kW}$. for Sizewell, and Sir William gave an estimate of $0.65 d$./u.s.o. for electricity generated at Sizewell, compared with about $0.5 d$. for moderm coal-fired stations situated near coalfields. However, he thought that it was probable that the estimated cost for the nuclear stations was likely to be reduced, as the assumptions for station life, fuel life and load factor were probably too conservative. The advanced gas-cooled reactor at Windscale should also reach full power in 1962 ; large stations of this type should offer generating costs competitive with the best coal-fired stations in the United Kingdom. To use in the 1970's the plutonium from the nuclear power stations, Britain had a vigorous programme of development of the fast reactor which, it was expected, would lead to large fast breeder power stations, fuelled with plutonium from the earlier nuclear stations. A detailed study had also been made of heavy-water moderated reactors, and consideration was being given whether or not to broaden Britain's programme by development in this field.

\section{U.S. Research Training Programmes in Medicine}

Nearly 6,000 sciontists and students are receiving research training under research training programmes described in a brochure published by the Department of Health Education and Welfare, Division of General Medical Sciences of the U.S. National Institutes of Health (Public Health Service Publication No. 865: Research Training Programs of the Division of General
Medical Sciences. Pp. vii +30 . Bethesda, Md.: Information Office, Division of General Medical Sciences, National Institutes of Health, 1962). The publication describes the purposes and activitios of the programmes under which the Division provides fellowships and grant support for graduate research training in the Nation's medical schools and other educational institutions. The medical and biological fields involved include the anatomical sciences, behavioural sciences, biochemistry, biomedical engineering, biometry, biophysical sciences, developmental biology, endocrinology, epidemiology, genetics, microbiology, nutrition, pathology, pharmacology and anæsthesiology, and physiology. The pamphlet also describes the special grant programme, which is concerned with the problems of specialized research manpower shortages; the medical student research training programme, which assists medical schools in the early identification, selection and research training of medical students who show promise for productive careers in academic medicine; and the research fellowships programme. The latter covers established research fellowships, including the predoctoral, postdoctoral and special fellowships, and the career award programme, the purpose of which is to provide an increased number of opportunities of stable careers for qualified candidates of superior potential and capability in the sciences related to health.

\section{Current Research and Development in Scientific Documentation}

THe ninth issue of Current Research and Develop. ment in Scientific Documentation covers projects relating to information needs and uses; information storage and retrieval; mechanical translation; equipment; and a miscellaneous section dealing with potentially related research, including linguistic and lexicographic research, artificial intelligence and psychological studies (National Science Foundation: Office of Science Information Service. NSF-61-76. Pp. xii +270 . Washington, D.C.: Government Printing Office. 1.25 dollars). Each section is preceded by a summary and the projects in each section are arranged alphabetically by authors or sponsors. Besides three projects of the Association of Special Libraries and Information Bureaux, British activities are repre. sented by projects from the National Book League, the National Physical Laboratory, the Scientific Documentation Centre, Dunfermline, and the Warren Spring Laboratory in the field of information storage and retrieval; Birkbeck College, the Cambridge Language Research Unit and the National Physical Laboratory in mechanical translation; and from Birkbeck College, the University of Manchester, the National Physical Laboratory, the University of Birmingham, the University of Cambridge, the University of Edinburgh, University College, London, and the Medical Research Council in the miscellaneous field.

\section{Bibliography of Low-Temperature Research}

IN the first issue of Cryogenics (September 1960) it was announced that bibliographical material covering the low-temperature field was being made available to the quarterly by Arthur D. Little, Inc., of Cambridge, Massachusetts. The material, re-classified and brought up to date by Dr. D. F. Brewer of the Clarendon Laboratory, Oxford, has recently been published as a separate supplement to Cryogenics, under the title "A Bibliography of Low Temperature Engineering and Research, 1944-60". There are 